\title{
How Significant was the Global Financial Crisis to Indonesia's Public Listed Housing Developers?
}

\author{
Abdul Rashid Abdul Aziz ${ }^{* 1}$, Toong Khuan Chan², Subashini Suresh ${ }^{3} \&$ Suresh Renukappa ${ }^{4}$ \\ ${ }^{1}$ Universiti Sains Malaysia, 11800, Penang, Malaysia \\ ${ }^{2}$ The University of Melbourne, Melbourne, Australia \\ 3,4 University of Wolverhampton, Wulfruna Street, Wolverhampton, United Kingdom \\ arashid@usm.my* \\ DOI: https://doi.org/10.37134/jcit.vo19.4.2019
}

\begin{abstract}
The tenth year anniversary of the Global Financial Crisis (GFC) provides an opportune moment to reflect on its true devastation on national industries. While many economists regard it as a global watershed, Indonesia was among the isolated few that emerged relatively unscathed. However it would be erroneous to assume that all of its economic sectors enjoyed the same fortune. A study was conducted to determine the most significant economic event for Indonesia's public listed housing developers in the years leading up to, and after the GFC. Panel data regression analysis was conducted on the financial data of the sampled companies. The analysis shows that the GFC of 2008 was not the most significant event for the study period for housing market players, nor was it the previous year when housing investor confidence was shaken. Instead that accolade goes to the event of 2012. While public-listed nonfinancial companies were affected by the Eurozone Crisis that year, a combination of factors resulted in public-listed housing developers enjoying record financial performance. The study underscores the importance of conducting deep sectoral analysis before arriving at any conclusions regarding the impact of external shocks on particular economic sectors.
\end{abstract}

Keywords: Indonesia; Panel data regression; Housing market; Sectoral analysis; Shocks

\section{INTRODUCTION}

A decade ago, on $15^{\text {th }}$ September 2008, Lehman Brothers filed for bankruptcy. For many analysts, that event marked the official beginning of the Global Financial Crisis (GFC) which rocked the world's economy to its foundation. The GFC has its roots in the United States' investors' loss of confidence in value of the sub-prime mortgages. The crisis rapidly reverberated around the world when stock prices in many countries plunged dramatically. Overall, Asian economies were not spared from the contagion. It was transmitted to Asian economies indirectly through the collapse in global demand and world trade (Lin and Treichel, 2012). Indonesia however stands out as the few Asian countries which weathered the GFC relatively unscathed because of a combination of factors including relatively small export share to GDP, appropriate policy responses by its government and central bank, and a pinch of good luck (Tambunan, 2010; Basri and Rahardja, 2010).

Even though the resilience of $16^{\text {th }}$ largest economy in world (World Bank 2017) to the GFC is well documented, little is known about its impact on Indonesia's primary housing sector. The housing market of any country is usually influenced by unique housing market conditions apart 
from macroeconomic shocks (Kim, 2008). And so, whatever that unfolds at the national level may not mirror at the primary housing sector level. Despite the GFC's strong links to the real estate, only a few scholars have focused on it when investigating the contagion (Milunovich and Truck, 2013). It is in response to this observation that this study was conducted.

The study sought to determine whether the GFC was the most significant event for Indonesia's primary housing market during an eight year period which straddled the GFC (i.e. 2004-2012). If it was, what other forces interplayed with the GFC to make it so? And if it was not, what was and why? Public listed housing developers were used as the proxy for the sector. There have been isolated studies that have looked at the impact of the GFC on national housing markets (Forrest and Yip, 2011; Murphy, 2011; Whitehead and Williams, 2011). This article adopted a different approach by taking a longer time horizon and providing more in-depth analysis on the macro-economic forces that played out over that period.

\section{LITERATURE REVIEW}

This section described the Indonesian economy leading up to, and following, the GFC. It also details the confluence of factors that attenuated the mega-shock.

Up until September 2008, the Indonesian economy still withstood the GFC which was already full-blown in the U.S. (Titiheruw et al., 2009). However, by the fourth quarter of 2008, the GFC began to exert on the Indonesian economy at an unprecedented rate (BI, 2009). Weakening exports, pressure on the balance of payments and turmoil on the money market bore down on economic growth. On the external side, deficit accumulated and the exchange rate underwent significant depreciation. Still, the Indonesian economy was able to chart $6.0 \%$ growth in 2008 , fueled by private consumption and exports. Domestic demand made up roughly two-thirds of the economy, which partially helped cushion Indonesia from the full wrath of the GFC. The economy continued on a downward trend the following year due to deep contraction in exports of goods and services (BI, 2010). By the end of 2009, the government implemented monetary and fiscal stimulus to combat the contagion. Economic growth was $4.6 \%$ that year, the third highest in the world after China and India. According to Wilczyńsk (2011) Indonesia was able to maintain high growth rate in 2009, while Thailand and Malaysia fell into recession because it had implemented a managed floating regime in 2009. By 2010, the Indonesian economy had recovered from the GFC as attested by the economic growth of $6.2 \%$, thanks to expansion in investment and exports (BI, 2011). Increased export performance was pronounced in the tradable sector, particularly the manufacturing industry, but also non-tradable sectors, primarily transport and communications, trading, hotels and restaurant.

Among its ASEAN neighbours, Indonesia suffered the least from the GFC. Thee (2012) offers four reasons why this was so. Firstly, Indonesia had a relatively low share of manufactures in its total exports. Its share of primary exports in its total merchandise exports was the highest compared to its neighbours of Malaysia, the Philippines and Thailand. Secondly, it had relatively low share of inter-regional trade in total trade, partly because of its ambiguous attitude towards foreign direct investment (FDI). Thirdly, its dependence export-led growth was relatively low. And finally, it was not largely exposed (in relation to its GDP) to banks in the US, EU and Japan, 
and had refrained from large credit exposures to sub-prime loans and securities in the US. The Asian Development Bank (2010) offer additional explanations:

1) risk aversion was muted by steady policy responses and the stabilising impact of coordinated global counter-measures on global financial markets;

2) fall in commodity prices was mitigated by preceding years' record high prices for these same commodities, allowing rural households to build up a savings buffer to help them smoothen out consumption spending;

3) GFC was of relatively short duration, and therefore the lagged effects of the financial crisis were absent;

4) government's good housekeeping of previous years provided it with the space to take swifter and more effective policy responses than in previous episodes of external shocks; and

5) balance sheets of the banking, corporate, and household sectors were much stronger than compared to the Asian Financial Crisis.

Echoing Asian Development Bank, the OECD (2012) mention that successful policy management and substantial reforms undertaken since the Asian Financial Crisis led to economic stability, notably the adoption of an inflation target and rules-based prudent fiscal framework. It also acknowledges that lower reliance on international trade than its regional peers also helped insulate the country from the global trade collapse.

\section{RESEARCH METHOD}

A total of 53 companies were listed in the Indonesia Stock Exchange, IDX, under the 'Property' sector during the study period. They had to fulfill the following criteria throughout the study period to qualify for the study: (a) listed in the local stock exchange, (b) no significant changes (e.g. mergers and acquisitions, disruption to financial year, suspension to trading status, etc.), and (c) revenue from property activities must be at least $50 \%$ of total. Only 18 companies made up the eventual sample.

All their financial results were extracted from annual reports and entered into Microsoft Excel spreadsheet. Aggregated figures were computed for total revenue, total profit, total assets, total liabilities and total equity. Five financial ratios were used to analyse the financial performance of the companies, namely profitability ratios, liquidity ratios, solvency ratios, efficiency ratios and market ratios. Because of size variation, a weight was applied to each ratio based on the annual revenue of the respective companies.

For panel data regression analysis, the statistical package E-Views 7. As 18 companies were observed for 9 years, 162 observations were made. The econometric model was developed which stated that net profit margin (denoted as Profit), return of average asset (ROAA) and return on average equity (ROAE) were dependent on debt ratio (denoted as Leverage), market capitalisation (denoted as Size) and market-to-book value (denoted as Growth):

$Y(P, R O A A, R O A E)_{i t}=\beta_{0}+\beta_{1} L_{i t}+\beta_{2} S_{i t}+\beta_{3} G_{i t}+\mu_{i t}$ 
where

$i=1,2, \ldots, 18$ (company)

$t=1,2, \ldots, 9$ (year)

$\mu_{i t}$ is a random error term

All market capitalisation values were converted to log value to standardised the data. The correlations between these 6 financial variables were examined by SPSS PASW (Predictive Analytics SoftWare). Of the three types of models - Pooled OLS Model, Fixed Effects Model and Random Effects Model - the latter was deemed the most appropriate after applying the Hausmen test.

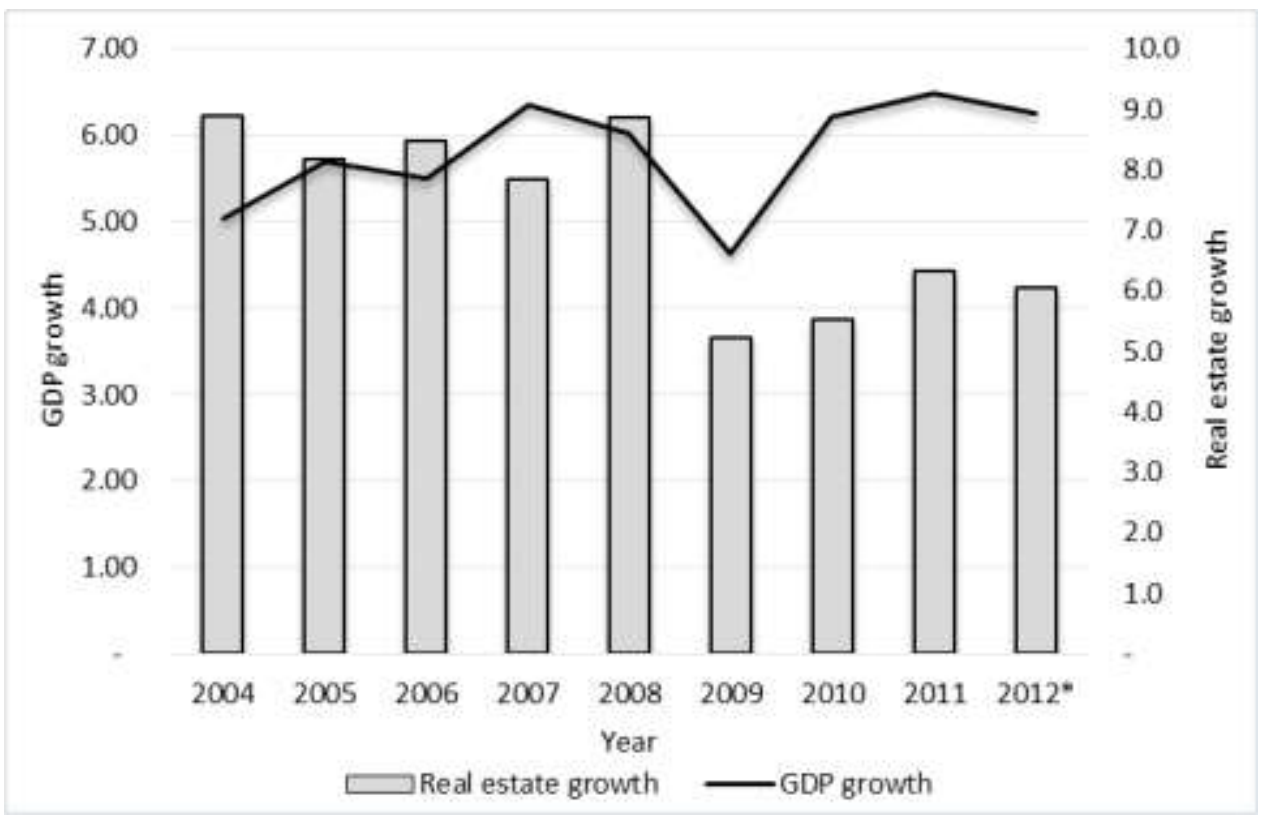

Figure 1. GDP and real estate GDP growth (at 2000 price) Source: Bank Indonesia

Indonesia experienced four dips in real estate GDP growth during the study period (see Figure 1) - a slight dip in 2005, another in 2007, sharp drop in 2009 and again a slight dip in 2012. Thus, 3 year-pairs were attempted; 2005 and 2007, 2007 and 2009 as well as 2007 and 2012. The purpose of these three year-pairs was to determine the most appropriate couple of dips to be analysed. The most significant year-pair was found to be 2007 (proxied by D1 dummy) and 2012 (proxied by D1 dummy).

Secondary sources of materials including reports from Bank Indonesia and international bodies as well as scholastic manuscripts were relied on to contextualise the financial analysis. The results were validated by a Singaporean real estate corporate figure with experience in Indonesia, and three university professors attached with two Indonesian universities. Indonesia's association of real estate - Reatestate Indonesia - ignored our invitation to participate in the research. 


\section{Findings and discussions}

The financial data and ratios of the sampled companies are shown in Table 1. Before presenting the results of the panel data regression analysis, the figures are briefly explained.

Table 1: Summary of financial data and ratios for the sampled companies (2004-2012) (monetary values in Rp billion)

\begin{tabular}{|c|c|c|c|c|c|c|c|c|c|}
\hline Year & 2004 & 2005 & 2006 & 2007 & 2008 & 2009 & 2010 & 2011 & 2012 \\
\hline Total revenue (TR) & 6,376 & 8,479 & 8,671 & 10,387 & 10,901 & 10,973 & 14,676 & 20,180 & 28,989 \\
\hline Profit before tax (PBT) & 519 & 1,753 & 2,193 & 2,247 & 2,310 & 2,363 & 3,833 & 5,171 & 7,608 \\
\hline Net profit (NP) & 398 & 1,803 & 1,983 & 1,368 & 1,307 & 1,548 & 2,861 & 4,002 & 6,952 \\
\hline $\begin{array}{l}\text { Total non-current assets } \\
\text { (TNCA) }\end{array}$ & 23,308 & 20,350 & 21,592 & 27,915 & 33,189 & 40,873 & 49,162 & 57,827 & 65,786 \\
\hline Total current assets (TCA) & 11,818 & 17,736 & 20,707 & 25,453 & 28,517 & 27,934 & 38,003 & 46,871 & 60,978 \\
\hline Total assets (TA) & 35,126 & 38,086 & 42,299 & 53,368 & 61,707 & 68,807 & 87,165 & 104,699 & 126,763 \\
\hline $\begin{array}{l}\text { Total current liabilities } \\
\text { (TCL) }\end{array}$ & 8,934 & 10,887 & 7,872 & 7,941 & 10,294 & 11,191 & 16,515 & 23,923 & 30,747 \\
\hline $\begin{array}{l}\text { Total non-current liabilities } \\
\text { (TNCL) }\end{array}$ & 17,459 & 12,161 & 13,619 & 15,361 & 16,454 & 19,880 & 18,893 & 20,633 & 27,464 \\
\hline Total liabilities (TL) & 26,393 & 23,048 & 21,490 & 23,302 & 26,749 & 31,071 & 35,408 & 44,555 & 58,211 \\
\hline Net assets (NA) & 8,733 & 15,038 & 20,809 & 30,066 & 34,958 & 37,736 & 51,397 & 59,698 & 68,552 \\
\hline Total equity (TE) & 8,725 & 15,030 & 20,801 & 30,059 & 34,952 & 37,731 & 51,726 & 60,144 & 68,551 \\
\hline Market capitalisation (MC) & 10,143 & 9,447 & 15,258 & 53,118 & 25,234 & 33,961 & 53,736 & 65,087 & 100,061 \\
\hline \multicolumn{10}{|l|}{ Profitability ratios } \\
\hline $\begin{array}{l}\text { Net profit margin }=(\mathrm{NP} / \\
\mathrm{TR})\end{array}$ & $(0.21)$ & 0.08 & 0.21 & 0.14 & 0.10 & 0.12 & 0.19 & 0.19 & 0.30 \\
\hline $\begin{array}{l}\text { Return on average } \\
\text { assets }=(\mathrm{NP} / \text { Average NA) }\end{array}$ & 0.02 & 0.04 & 0.06 & 0.03 & 0.02 & 0.02 & 0.05 & 0.04 & 0.08 \\
\hline $\begin{array}{l}\text { Return on average } \\
\text { equity }=(\mathrm{NP} / \text { Average } \mathrm{TE})\end{array}$ & $(0.01)$ & 0.04 & 0.08 & 0.06 & 0.06 & 0.05 & 0.08 & 0.08 & 0.17 \\
\hline \multicolumn{10}{|l|}{ Efficiency ratios } \\
\hline $\begin{array}{l}\text { Sales to assets } \\
\text { ratio }=(\mathrm{TR} / \text { Average } \mathrm{TA})\end{array}$ & 0.18 & 0.23 & 0.27 & 0.20 & 0.20 & 0.18 & 0.25 & 0.22 & 0.27 \\
\hline \multicolumn{10}{|l|}{ Liquidity ratios } \\
\hline Current ratio $=(\mathrm{TCA} / \mathrm{TCL})$ & 3.31 & 3.94 & 7.21 & 4.41 & 5.67 & 5.76 & 7.37 & 4.82 & 5.09 \\
\hline $\begin{array}{l}\text { Quick ratio=(TTCA- } \\
\text { Inventory/TCL) }\end{array}$ & 0.90 & 1.17 & 1.79 & 1.97 & 2.48 & 2.46 & 3.35 & 2.22 & 2.56 \\
\hline \multicolumn{10}{|l|}{ Leverage ratios } \\
\hline Debt ratio $=(\mathrm{TL} / \mathrm{TE})$ & 0.52 & 0.46 & 0.44 & 0.37 & 0.50 & 0.43 & 0.42 & 0.42 & 0.48 \\
\hline Debt to equity $=(\mathrm{TL} / \mathrm{TE})$ & -0.05 & 0.72 & 2.74 & 0.78 & 1.18 & 0.95 & 0.86 & 0.90 & 1.05 \\
\hline \multicolumn{10}{|l|}{ Market ratio } \\
\hline Earnings per share & 13.84 & 47.66 & 48.44 & 18.80 & 17.65 & 19.36 & 32.84 & 41.82 & 72.56 \\
\hline Price-earnings ratio & $(0.94)$ & $(0.38)$ & 22.62 & 59.07 & $(11.40)$ & 34.07 & 20.63 & 19.08 & 20.55 \\
\hline
\end{tabular}


The aggregated total revenue of the sample companies grew slowly before making tremendous growth in 2010 and thereafter as the Indonesian economy made a full recovery. Profit before tax and net profit mirrored the same trend. The compound annual growth rate (CAGR) for total revenue, profit before tax and net profit from 2004 to 2012 were $18.3 \%, 34.8 \%$ and $37.4 \%$ respectively. Total assets also enjoyed tremendous growth in the last three years of the study period. Interestingly total assets also spiked in 2007. The CAGR for total assets was $15.3 \%$, which was less than for total revenue, implying that the companies utilised well the assets to generate income. Total liabilities reduced initially and then increased by larger amount from 2007 onwards. The CAGR for total liabilities was $9.2 \%$ which was lower for total assets, indicating that the companies possessed adequate resources to fulfill their debt obligations, which was a positive sign. Net assets recorded a healthy growth with CAGR of $25.7 \%$, which was nearly triple the CAGR of total liabilities. This implies that the companies were successful in managing debts and obligations. Market capitalisation spiked in 2007 and crashed during the 2008 global financial meltdown. But it rebounded with vigour thereafter.

All three profitability ratios were on an uptrend but recorded negative growths in 2007 and 2008, though interestingly the worse year was the former. The best year for all three was 2012. Sales to assets ratio fluctuated but slipped downwards the most in 2007 and rebound vigorously in 2010. Liquidity ratio measures the ability to pay off short-term debts obligations. The greater ratio, the better the safety margin to cover short run debts. The sampled companies tried to keep the ratios in an uptrend but suffered setbacks in 2007 and 2011. Leverage ratios measure the company's abilities to meet its obligations. The greater the ratio, the higher is the risk exposure. Debt ratios were fairly stable throughout the study period, except in 2006 when debt-to-equity ratio recorded an upsurge. Notwithstanding this anomaly, the leverage ratios were in a healthy range and the companies were exposed to low financial risk. And the reason why the leverage ratios are as such is that several sampled companies converted their debt to equity at various times. As for market ratios, earnings per share decreased dramatically in 2007 and exponentially recovered by 2012. Price per earnings ratio spiked in 2007 and crashed in 2008.

From the financial analysis above, it is difficult to decipher which year was the most significant for the sample companies. Hence the need for panel regression analysis. As mentioned in the previous section, it was identified that 2007 and 2012 were the best paired years for panel regression analysis. It is intriguing that 2008, the year the GFC was full-blown, did not appear.

The initial model for net profit margin generated from E-Views 7 suffered from normality and autocorrelation problems. Log transformation of data was done to all independent and dependent variables (excluding dummies and size variable since they were already in log form). This transformation was necessary to solve the problem with linearity. The transformed model of profit is shown in Table 2. It shows that net profit margin was influenced by debt ratio, marketto-book value and the event in 2012. 
Table 2: Transformed model of net profit margin

Dependent Variable: LNPROFIT

Method: Panel EGLS (Cross-section random effects)

Sample: 20042012

Periods included: 9

Cross-sections included: 18

Total panel (balanced) observations: 162

Swamy and Arora estimator of component variances

\begin{tabular}{|c|c|c|c|c|}
\hline Variable & Coefficient & Std. Error & t-Statistic & Prob. \\
\hline C & 0.568358 & 0.083884 & 6.775512 & 0.0000 \\
\hline LNLEVERAGE & 0.036613 & 0.013073 & 2.800697 & 0.0057 \\
\hline LNGROWTH & 0.103930 & 0.042947 & 2.419939 & 0.0167 \\
\hline \multirow[t]{3}{*}{ D2 } & 0.071732 & 0.033511 & 2.140517 & 0.0338 \\
\hline & \multirow{2}{*}{\multicolumn{2}{|c|}{ Effects Specification }} & & \\
\hline & & & S.D. & Rho \\
\hline \multirow{3}{*}{$\begin{array}{l}\text { Cross-section random } \\
\text { Idiosyncratic random }\end{array}$} & & & 0.029340 & 0.0464 \\
\hline & & & 0.133077 & 0.9536 \\
\hline & \multicolumn{3}{|c|}{ Weighted Statistics } & \\
\hline R-squared & 0.105108 & \multicolumn{2}{|c|}{ Mean dependent var } & 0.616027 \\
\hline Adjusted R-squared & 0.088117 & \multicolumn{2}{|c|}{ S.D. dependent var } & 0.144211 \\
\hline S.E. of regression & 0.137711 & \multicolumn{2}{|c|}{ Sum squared resid } & 2.996361 \\
\hline F-statistic & 6.185894 & \multicolumn{2}{|c|}{ Durbin-Watson stat } & 1.542840 \\
\hline Prob(F-statistic) & 0.000532 & & & \\
\hline
\end{tabular}

Durbin-Watson statistic, $\mathrm{d}$ was applied to detect the autocorrelation in the model. From Table $2, d$ was 1.542840 with $\mathrm{N}=162$ and $\mathrm{k}=3$. At $5 \%$ level of significance, the value of lower value, $d_{L}$ $=1.704$ and upper value, $d_{U}=1.780$ were obtained from the DW Statistic Table. The DW value, $\mathrm{d}$ was smaller than $d_{L}$, thus the null hypothesis which stated "no autocorrelation" was rejected. The error terms are not independent from observation to observation. According to Croux et al. (2003), the standard error of a model is robust if it is still consistent though the regression errors are autocorrelated/or heteroskedastic. The standard error of regression (SE) for LNPROFIT, LNLEVERAGE, LNGROWTH and D2 was small (0.1377), thus indicating reliability. As the reliability increased, the SE decreased. The equation of the transformed model for net profit margin (denoted by profit) was: 


\section{LNPROFIT $=0.5684+0.0366 L N L E V E R A G E+0.1039 L N G R O W T H+0.0717 D 2$}

The equation shows that net profit margin was positively influenced by debt ratio (denoted by Leverage), market-to-book value (denoted by Growth) and the event in 2012. Whenever there was an increase of 1 unit of debt ratio and market to book value respectively in the presence of the event of 2012, aggregated net profit margin of 18 companies was 1.90 .

The initial model for return on average asset (ROAA) generated from E-Views 7 also suffered from normality and autocorrelation problems. Likewise, log transformation of data was done to all independent and dependent variables, except dummies and size variable.The initial model also showed that only Growth and D2 were significant at $\alpha=0.05$ towards ROAA. Thus, Leverage, Size and D1 were omitted from the transformed model of ROAA which is shown in Table 3. It shows that ROAA was influenced by market-to-book value and the event of 2012.

Table 3: Transformed model of ROAA

Dependent Variable: LNROAA

Method: Panel EGLS (Cross-section random effects)

Sample: 20042012

Periods included: 9

Cross-sections included: 18

Total panel (balanced) observations: 162

Swamy and Arora estimator of component variances

\begin{tabular}{ccccc}
\hline \hline Variable & Coefficient & Std. Error & t-Statistic & Prob. \\
\hline \hline C & -0.032308 & 0.025693 & -1.257448 & 0.2104 \\
LNGROWTH & 0.032808 & 0.013060 & 2.512105 & 0.0130 \\
D2 & 0.035032 & 0.009920 & 3.531237 & 0.0005 \\
\hline \hline & Effects Specification & & \\
\hline \hline & & & S.D. & Rho \\
Cross-section random & & 0.022847 & 0.2517 \\
Idiosyncratic random & & & 0.039392 & 0.7483 \\
\hline
\end{tabular}

Weighted Statistics

$\begin{array}{llll}\text { R-squared } & 0.117758 & \text { Mean dependent var } & 0.017185 \\ \text { Adjusted R-squared } & 0.106660 & \text { S.D. dependent var } & 0.041685 \\ \text { S.E. of regression } & 0.039399 & \text { Sum squared resid } & 0.246818 \\ \text { F-statistic } & 10.61129 & \text { Durbin-Watson stat } & 1.456811 \\ \text { Prob(F-statistic) } & 0.000047 & & \end{array}$


Durbin-Watson statistic, $d$ was applied to detect the autocorrelation in the model. From Table $3, d$ was 1.456811 with $\mathrm{N}=162$ and $\mathrm{k}=2$. At $5 \%$ level of significance, the value of lower value, $d_{L}=1.716$ and upper value, $d_{U}=1.767$ were obtained from the DW Statistic Table. The DW value, $d$ was smaller than $d_{L}$, thus the null hypothesis which stated "no autocorrelation" was rejected. The error terms are not independent from observation to observation. According to Croux (2003), the standard error of a model is robust if it is still consistent though the regression errors are autocorrelated/or heteroskedastic. The standard error of regression (SE) for LNROAA, LNGROWTH and D2 were small (0.0394), thus indicating reliability. As the reliability increases, the SE decreases. The equation of the transformed model for ROAA was:

$$
\text { LNROAA }=-0.0323+0.0328 L N G R O W T H+0.0350 D 2
$$

The equation shows that ROAA was positively influenced by market-to-book value (denoted by Growth) and the event in 2012. When there was an increase of 1 unit of market to book value and in the presence of the event of 2012, the aggregated ROAA of the 18 companies was 1.00.

From the initial model for return on average equity (ROAE) generated from E-Views 7, it was observed that only market capitalisation and market-to-book value were significant at $\alpha=0.05$ towards ROAE. However it too suffered from normality and autocorrelation problems. The transformed model of ROAE is shown in Table 4.

Table 4: Transformed model of ROAE

Dependent Variable: ROAE

Method: Panel EGLS (Cross-section random effects)

Sample: 20042012

Periods included: 9

Cross-sections included: 18

Total panel (balanced) observations: 162

Swamy and Arora estimator of component variances

\begin{tabular}{crrrr}
\hline \hline Variable & Coefficient & Std. Error & t-Statistic & Prob. \\
\hline C & -0.698003 & 0.270630 & -2.579183 & 0.0108 \\
SIZE & 0.031448 & 0.010128 & 3.105034 & 0.0023 \\
GROWTH & -0.132018 & 0.019389 & -6.808746 & 0.0000 \\
\hline \hline & Effects Specification & & \\
& & & S.D. & Rho \\
\hline \hline Cross-section random & & 0.039294 & 0.0126 \\
Idiosyncratic random & & 0.348167 & 0.9874 \\
\hline \hline & Weighted Statistics & & \\
\hline \hline R-squared & \multirow{2}{*}{0.229135} & Mean dependent var & 0.021844
\end{tabular}




\begin{tabular}{llll} 
Adjusted R-squared & 0.219439 & S.D. dependent var & 0.398816 \\
S.E. of regression & 0.352352 & Sum squared resid & 19.74014 \\
F-statistic & 23.63094 & Durbin-Watson stat & 2.157900 \\
Prob(F-statistic) & 0.000000 & & \\
\hline \hline
\end{tabular}

Durbin-Watson statistic, $d$ was applied to detect the autocorrelation in the model. From Table 4, $d$ was 2.157900 with $\mathrm{N}=162$ and $\mathrm{k}=2$. At $5 \%$ level of significance, the value of lower value, $d_{L}=1.716$ and upper value, $d_{U}=1.767$ were obtained from the DW Statistic Table. The DW value, $d$ was greater than $d_{U}$, thus the null hypothesis which stated "no autocorrelation" is accepted. The model was free from autocorrelation. The equation of the transformed model for ROAE was:

$$
R O A E=-0.6980+0.0314 S I Z E-0.1320 G R O W T H
$$

The ROAE was positively related to market capitalisation (denoted by Size) and negatively related to market-to-book value (denoted by Growth). What is important to note is that it was not influenced by the event in 2012. When there was an increase of 1 unit of market capitalisation and market to book value, the ROAE was -0.80 .

To summarise, the panel regression analysis found that the event of 2012 had a positive influence on net profit margin and ROAA, but not ROAE. This finding contrasted with Bank of Indonesia's (2013b) observation that the financial performance of public-listed non-financial companies were negatively impacted by the slowdown in international trade activity in the same year due to the Eurozone Crisis. Put simply, while public-listed non-financial companies endured hard times in 2012, public-listed housing development companies were enjoying the opposite. Indeed as shown in Table 1, the net profit margin, ROAA (and even ROAE) augmented appreciably for the sample companies that year. It is also noteworthy that the average increase of profit before tax for 2012 from the previous year was $47 \%$.

The panel regression analysis results begs the question: what was the event of 2012 that led to the excellent financial performance? But before that question is answered, the next sub-section probed into what event that unfolded in 2007 that led the year to being paired up with 2012.

\section{Events of 2007}

Before the sub-prime crisis unfolded in the second half of 2007, Indonesia enjoyed robust economic growth (Goh et al., 2011) The favourable performance was resultant of significant surplus of balance of payments reinforcing the international reserves, exchange rate stability, strong credit expansion and inflation that was under control. In the second half of 2007 however, the Indonesian economy experienced the knock-on effects of the sub-prime mortgage crisis, as well as price hike in oil and other international commodities thereby threatening purchasing power with prospect of higher production cost, among others. The high oil price prompted the government to execute the cut-off domestic oil subsidy, thus contributing to capital reversal by some foreign investors (Ismal, 2013). The combination of all these deleterious forces affected 
assets in Indonesia and also triggered a round of capital reversal on the domestic financial market, with Bank Indonesia Certificate (SBI), government securities and stocks most affected. The portfolio outflow led to large declines in their assets credit growth (Isnawangsih et al., 2013). Investor confidence was affected, and as a consequence real estate growth slowed down slightly to $7.9 \%$ as opposed to $8.5 \%$ in 2006 (see Figure 2).

Despite this capital flight in 2007, Indonesia actually experienced only a mild moderation because of the small size of the banking system and capital market (Isnawangsih et al., 2013). Remarkably, the economy recorded better growth in 2007 (i.e. 6.3\%) compared to the previous year (i.e. 5.5\%). The same cannot be said for the real estate sector which moved in opposite direction to the general economic recording $7.9 \%$ growth in 2007 as opposed to $8.5 \%$ growth the previous year (see Figure 1).

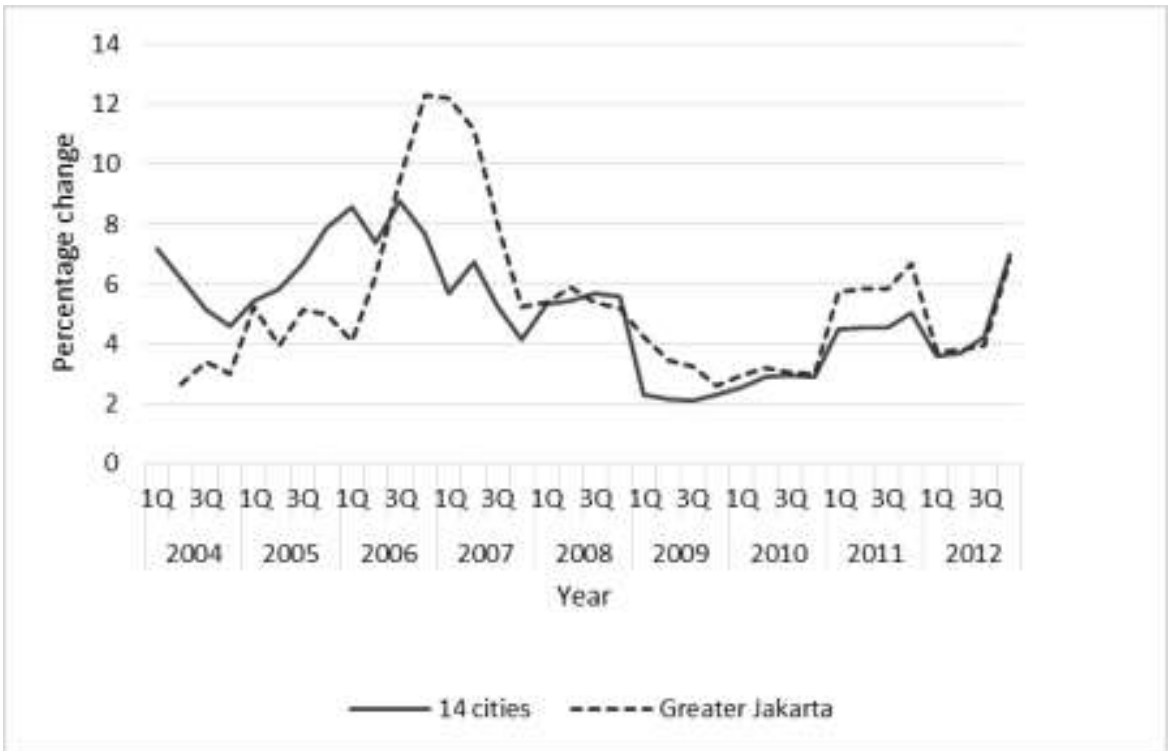

Figure 2. Percentage change in residential property price index (year on year) for national level and Greater Jakarta. Source: Bank Indonesia Note: The nationwide data is actually for 14 major Indonesian cities including Greater Jakarta.

But the situation could have been worse for the primary housing market if not for a mixture of government intervention and fortuitous cirumstance (Isnawangsih et al., 2013). Bank Indonesia reduced its interest rate from 9.75\% in December 2006 to 8.00\% in December 2007 (see Figure 3), spurring a healthy growth in mortgage loans. Bank mortgage rates hovered around 10\% per annum that year. Inflation rate was also fairly low at that time (see Figure 4). 


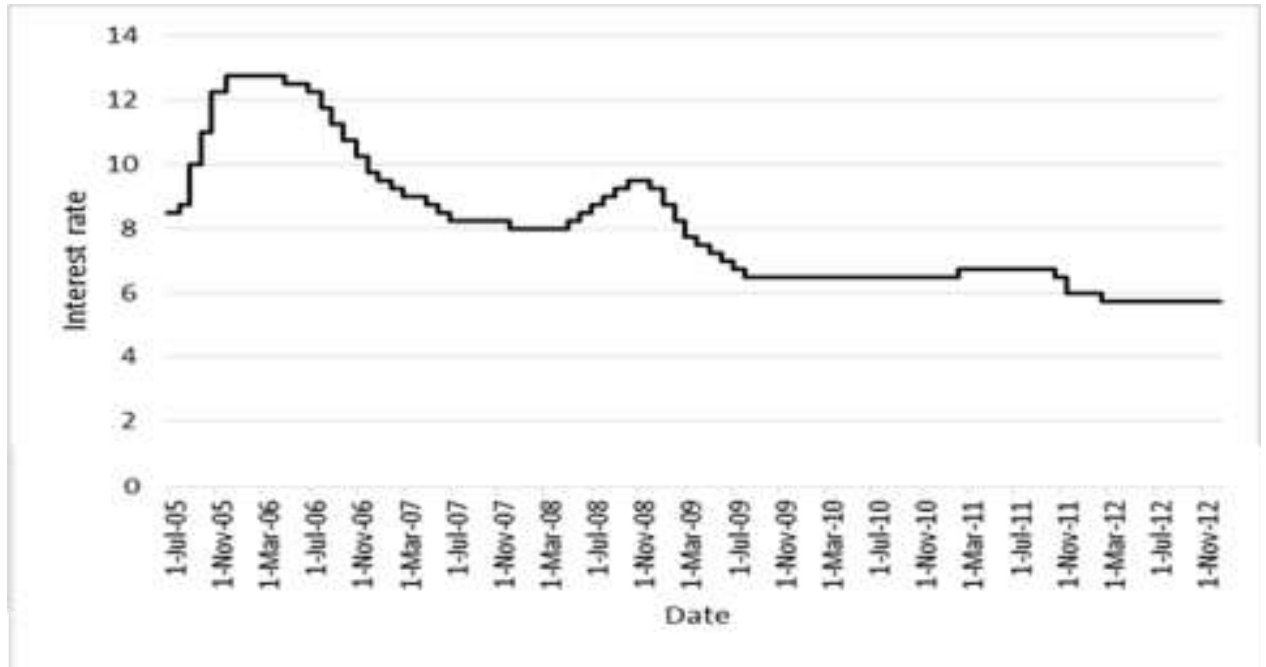

Figure 3. Rupiah interest rate spread Source: Bank Indonesia.

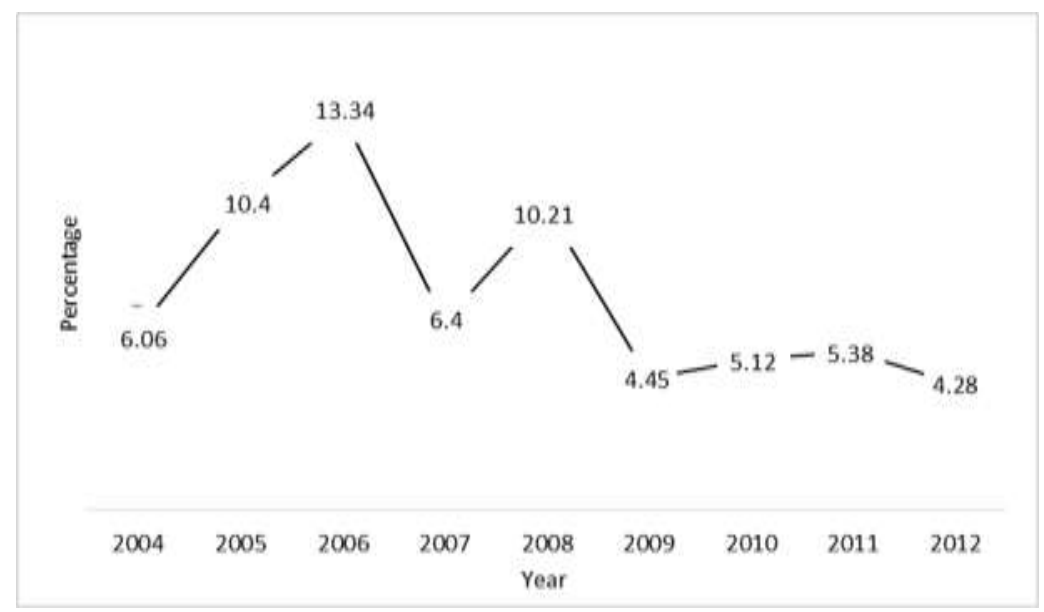

Figure 4. Consumer price index.

Source: Government of Indonesia.

Events of 2012

The panel regression analysis shows that the 2012 event positively eclipsed the event in 2007. As evident from the financial data and ratios (see Table 1), the sampled companies began to record healthy financial performance from 2010 onwards which peaked in 2012, which was the year the Eurozone Crisis erupted. This is an anomaly that requires explanation.

The Indonesian economy was not entirely insulated from the damaging effect of the Eurozone Crisis which was transmitted via the trade channel (BI, 2012). Indonesia's export slumped, exacerbated by the drop in prices of several commodities such as palm oil, coal and crude oil. As a counteracting measure, Indonesia diverted its exports to include ASEAN countries as well as South Korea and Taiwan. Also, trade finance shrunk due to limited expansion activities by 
European banks as a result of deleveraging. But as Figure 1 shows, the Indonesian economy contracted only slightly that year, from $6.5 \%$ to $6.2 \%$.

Indonesia were less affected by the drop in global demand compared to other Asian neighbours which had strong trading links with Europe because of its strong domestic demand (Rana and Blomenhofer, 2013; ADB, 2013). Indeed, the Indonesian government admitted that solid domestic consumption propped up the national economy (BI, 2013a). This robust domestic demand is attributable to rising real public purchasing power and widening consumer base as the Indonesian middle class grew larger. Household consumption was also strong because of consumer confidence level was high (see Figure 5). Strong economic growth in the preceding two years had boosted consumer confidence. According to official statistics, household consumption registered a $5.3 \%$ growth in 2012 , up from the previous year of $4.7 \%$. It was this solid domestic demand that counteracted the slowdown in exports.

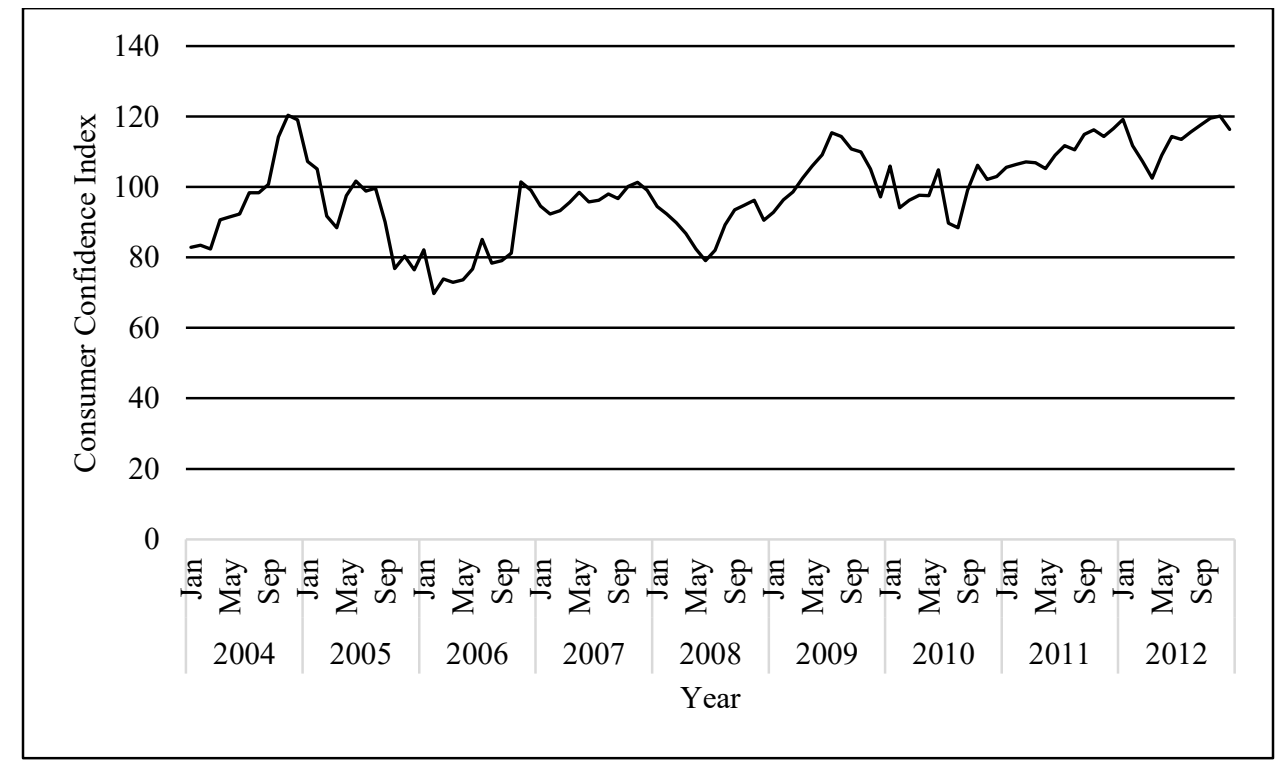

Figure 5. Consumer Confidence Index Source: Bank Indonesia

Concurrently, there was another force that acted on the Indonesian economy in a positive way: sound investment. While other Asian countries experienced a sharp drop of FDI inflow due to heavy dependence on the European Union (EU) (Rana and Blomenhofer, 2013), Indonesia on the other hand enjoyed increased FDI amounting to US\$34.5 billion in 2012, up 42.2\% from the previous year (BI, 2013b), most of it going to manufacturing and mining sectors (excluding oil and gas) (ADB, 2013). The structural reforms to improve investment climate which was implemented in the mid-2000s finally paid off (Isnawangsih et al, 2013).

Solid domestic demand and healthy FDI stream boosted the local property market (Dermawan and Setyoningsi, 2012). Though expatriates and foreign businessmen were subjected to strict restrictions when it comes to house purchase, they still needed residences just as local workers especially in industrial areas. Inflation rate which incidentally was the lowest throughout 
the study period (see Figure 4) also boosted borrowing for house purchases (Dermawan and Setyoningsih, 2012). Also, borrowing for home purchases was never as attractive as in 2012, thus fueling further the housing purchase boom. Ever since April 2006 when interest rate was 12.75\%, there has been a downward trend in interest rate to an all-time low of 5.75\% (see Figure 3 ).

There was another factor that drove sales of housing up, and it had to do with financial regulation. In 2012, Bank Indonesia implemented a raft of macro-economic tools to control liquidity in the economy, one of which was the loan-to-value (LTV) ratio effective 15 June 2012 as spelt out in Circular No 14/10/DPNP dated 15 ${ }^{\text {th }}$ March 2012 (OECD, 2012; BI 2012; BI, 2013b). Banks were given a transition period of three months for them to harmonise their Standard Operating Procedures (SOP), disseminate information as well as to adjust their reporting system to Bank Indonesia. The LTV ratio was set at the maximum of $70 \%$ for residential loans of building types (including flats and apartments) over $70 \mathrm{~m}^{2}$. Residential loans under government programmes were exempted. The LTV policy was intended to safeguard the growth of residential loans properties above $70 \mathrm{~m}^{2}$ from potential debtors with inadequate financial capacity and speculative behaviour (BI, 2012). But what actually transpired was that banks accelerated residential financing for such properties ahead of the deadline. There was high growth of residential loans for the residential type of over $70 \mathrm{~m}^{2}$ in June 2012 amounting to 32\% (y-o-y) in contrast to $12 \%$ in June the previous year. The growth of over $70 \mathrm{~m}^{2}$ properties began to slow down to 43\% (y-o-y) in September 2012 compared to 62\% (y-o-y) in September 2011. However, it bounced back to $48 \%$ (y-o-y) in December 2012 compared to 27\% in December 2011 in part due to cyclical end-of-year residential loan growth. Overall, loans in December 2012 grew by 21.7\% from the previous year to reach IDR222.35 trillion (US\$22.79 billion).

The combination of strong domestic demand, sound FDI, low inflation, favourable interest rate and impending LTV regulation boosted housing demand which is reflected in the residential Property Price Index rising in the fourth quarter of 2012 by $7.0 \%$ (year on year) (BI, 2013c) (see Figure 2). Residential property sales volume in 2012 rose by $26.7 \%$. For small houses, the increase was even more pronounced - approximately 41\% increase in the fourth quarter of 2012 (y-on-y).

\section{CONCLUSION}

The above analysis which stretched from 2004-2012 shows that the GFC of 2008 did not impinge on the financial performance of public listed housing development companies to the extent that other events did. In fact the subprime mortgage which unfolded a year before did. However between that 2007 event and that which took place in 2012, the latter was more significant. Again, investigations revealed that it was not the Eurozone Crisis that triggered significant financial performance of the sampled companies as one might assume. Instead it was a combination of domestic factors that included high consumer confidence, FDI inflow, low inflation, attractive interest rate and impending LTV regulation and that made 2012 such a significant year for the sample public listed housing developers. It is so easy to regard the GFC as the watershed for many national economies and their constituent sectors. What this study has underscored is that only proper analysis can reveal whether this generalisation holds true. In fact, it might even uncover unexpected results. 


\title{
ACKNOWLEDGEMENT
}

\author{
This work was supported by the National Property Research Coordinator (NAPREC) of Malaysia.
}

\section{REFERENCES}

Asian Development Bank. (2010). Country diagnostic studies: Indonesia: Critical development constraints. Metro Manila, Philippines: ADB.

Asian Development Bank. (2013). Asian development outlook 2013. Asia's energy challenge. Mandluyong City, Philippines: ADB.

Bank Indonesia. (2009). 2008 Economic report on Indonesia. Jakarta.

Bank Indonesia. (2010). 2009 Economic report on Indonesia. Jakarta.

Bank Indonesia. (2011). 2010 Economic report on Indonesia. Jakarta.

Bank Indonesia. (2012). Financial stability review, No 19. September, Jakarta.

Bank Indonesia. (2013a). 2012 Economic report on Indonesia. Jakarta.

Bank Indonesia. (2013b). Financial stability Review, No 20. March. Jakarta

Bank Indonesia. (2013c). Residential property price survey Quarter IV - 2012. Jakarta

Basri, M.C., \& Rahardja, S. (2010). The Indonesian economy amidst the Global Crisis: Good policy and good luck. ASEAN Economic Bulletin 27(1), 77-97.

Croux, C., Dhaene, G. \& Hoorelbeke, D. (2003) Robust standard errors for robust estimators (Discussion Paper Series (DPS) 03.16). Dec Faculty of Economics and Applied Economics, Leuven, Belgium: Katholieke Universiteit/ Retrieved from http://www.econ.kuleuven.be/ces/discussionpapers/default.htm

Dermawan, D. \& Setyoningsih, T. (2012). Indonesia's residential property price index. Paper presented at the 31st CIRECT Conference on Economc Tendency Surveys and Economic Policy, Sept 5-8, Vienna, Austria. Retrieved from https://www.ciret.org/media/ciret papers/vienna-2012/p 132-710790.pdf.

Forrest, R. \& Yip, N.M., eds. (2011). Housing markets and the Global Financial Crisis: The uneven impact on households. Cheltenham, Glos.: Edward Elgar Publishing Ltd.

Goh, J., Adiningsih, S. \& Gochoco-Bautista, M.S. (2011). Lessons from the Financial Crisis: Report of the Asian Financial Regulatory Committee. In The World in crisis: Insights from six shadow financial regulatory committees from around the world, edited by R. Litan, 61-124. Philadelphia, USA: FIC Press.

Ismal, R. (2013). Islamic banking in Indonesia: New perspectives on monetary and financial issues. Singapore: John Wiley and Sons.

Isnawangsih, A., Klyuev, V. \& Zhang, L. (2013). The big split: Why did output trajectories in the ASEAN-4 diverge after the Global Financial Crisis? (IMF Working Paper 13/222). Washington: IMF.

Kim, K.H. (2008). Housing and the Korean economy. Journal of Housing Economics, 13(4), 321-341.

Lin, J. Y. \& Treichel, V. (2012). The Unexpected Global Financial Crisis: Researching its Root Cause (Policy Research Working Paper 5937).Washington: The World Bank.

Milunovich, G. \& Truck, S. (2013). Regional and global contagion in real estate investment trusts: The case of the Financial Crisis of 2007-2009. Journal of Property Investment E Finance, 31(3), 53-77.

Murphy, L. (2011). The Global Financial Crisis and the Australian and New Zealand housing markets. Journal of Housing and the Built Environment, 26(3), 335-351.

Organisation for Economic Co-operative and Development. (2012). OECD Economic Surveys. Indonesia, September, Paris.

Rana, P.B. \& Blomenhofer, M. (2013). The Eurozone and its impact on Asia (RSIS Working Paper No 254, Feb.) Singapore: Nanyang Technological University.

Tambunan, T.T.H. (2010). The Indonesian experience with two big economic crises. Modern Economy, 1, $156-167$.

Thee, K.W. (2012). The Indonesian economy after the Global Financial Crisis. Retrieved from https://crawford.anu.edu.au/acde/ip/pdf/lpem/2012/2012_10_24_-_SEADI_Thee_Kian_Wie.pdf.

Titiheruw, I.S., Soesastro, H. \& Atje, R. (2009). Global Financial Crisis Discussion Series Paper 6: Indonesia. London: Overseas Development Institute. 
Wilczyński, R. (2011). Global financial governance: A perspective from the International Monetary Fund. Contemporary Economics, 5(1), 4-16.

Whitehead, C. \& Williams, P. (2011). Causes and consequences? Exploring the shape and direction of the housing system in the UK post the financial crisis. Journal of Housing Studies, 26(7-8), 1157-1169.

World Bank. (2017). World development indicators database. Retrieved at 17 April from databank.worldbank.org/data/download/GDP.pdf. Accessed on 11 December 2017 